\title{
Kesadaran Beragama dalam Perspektif Ihsan: Pengalaman Pertaubatan Preman
}

\author{
Heryanto*1 $^{*}$ \\ ${ }^{1}$ Universitas Mulawarman, Indonesia \\ Email: heryfe@yahoo.co.id
}

\begin{abstract}
The initial aim was to analyze and evaluate the development of thuggery religious awareness, in order to obtain an overview of the processes, patterns, and factors that influence it. This has done because the subject has changed behavior in religious awareness. This research method has used a qualitative approach, case studies. The sample in this study has used a purposive sampling technique, while the key informants snowball sampling technique. The focus of this research is the religious awareness behavior of thuggery. The data collected by observation, interview, the questionnaire as a guide, and documentation. The results of the study show that religious awareness is a condition that must achieved through the struggle of the person concerned. Strong intrinsic motivation plays a role in religious awareness and repentance. The bad behavior of thuggery has caused by a bad social environment. Family and friends can help someone to repent. The Ulama guidance becomes the way of religious awareness. Childhood religious education plays an important role in fostering adult religious awareness.
\end{abstract}

Keywords: religious awareness; religiosity; thuggery.

\begin{abstract}
Abstrak
Tujuan penelitian ini adalah menganalisis dan mengevaluasi perkembangan kesadaran beragama pada preman, sehingga diperoleh gambaran tentang proses, pola dan faktor-faktor yang mempengaruhinya. Hal ini dilakukan karena subyek mengalami perubahan perilaku dalam kesadaran beragama. Metode penelitian ini menggunakan pendekatan kualitatif studi kasus. Sampel pada penelitian ini menggunakan teknik purposive sampling, sedangkan informan kunci menggunakan teknik snowball sampling. Fokus utama penelitian ini adalah perilaku kesadaran beragama seorang preman sesuai fitrahnya. Data penelitian dikumpulkan melalui observasi, wawancara, kuesioner sebagai panduan, dan dokumentasi Hasil penelitian memperlihatkan bahwa kesadaran beragama pada diri seseorang merupakan sesuatu yang harus diraih melalui perjuangan pada orang yang bersangkutan. Motivasi intrinsik yang kuat sangat berperan menumbuhkan kesadaran beragama dan melakukan pertaubatan. Perilaku buruk seseorang preman disebabkan oleh lingkungan sosial yang buruk. Keluarga dan kerabat dapat menjadi sarana pertaubatan. Bimbingan ulama adalah jalan pada kesadaran beragama. Pendidikan agama pada masa kecil berperan penting dalam menumbuhkan kesadaran beragama setelah dewasa.
\end{abstract}

Kata Kunci: Premanisme; kesadaran beragama; relijiusitas.

\section{PENDAHULUAN}

Perilaku manusia yang berkarakter tidak terpuji, seperti premanisme tidak selamanya berakhir dengan buruk, namun terdapat di antara mereka berakhir dengan akhlak mulia sesuai dengan adat istiadat masyarakat dan tuntunan agama. Seseorang yang semula berperilaku menyimpang dari norma sosial dan agama kemudian mengubah jalan hidupnya menjadi hidup lebih baik tidak terjadi secara tiba-tiba, tetapi melalui proses dan pola-pola tertentu. Kehidupan premanisme merupakan contoh kelompok masyarakat yang berperilaku menyimpang,

Kehadiran premanisme di lingkungan masyarakat Ibu Kota Provinsi Kalimantan Timur telah banyak membuat keresahaan dan ketidakamanan. Perbuatannya mulai dari pemalakan, 
penjambretan, pencopetan, perampasan barang, pencurian, perampokan, pemerkosaan dan yang paling mengerikan sampai pada pembunuhan. Preman adalah perilaku seseorang yang membuat resah masyarakat atau lingkungan sekitar dan orang lain yang dilakukan secara sendiri atau berkelompok untuk kepentingan pribadinya sendiri (Wahyuningsih, 2018). Alih-alih ada sekelompok premanisme yang mendapat perlindungan (backing) dari oknum penguasa yang teroganisir. Hal ini menunjukan bahwa negara telah gagal menjalankan tugasnya, seringkali para preman nampak di dalam media cetak dan televisi tidak ditindak sesuai hukum, dan bahkan mereka nampak bagai pahlawan di dalam komunitasnya. Pembiaran ini akan semakin menyuburkan tindak kekerasan dan membuat kita semakin terpuruk (Supriadi, Yophi, and Ramadhan, 2013). Orang sering lupa bahwa banyak pelaku atau pelanggar hukum adalah orang-orang yang mempunyai otoritas di bidang hukum sehingga mereka dapat "mempermainkan" hukum yang ada (Irwanto, 2016). Keadaan ini menjadi infrastruktur terbaik bagi para pelaku pelangaran hukum lainnya, termasuk premanisme.

Pada awalnya, seseorang tidak terlintas dalam pikirannya untuk menjalani hidup menjadi seorang preman, namun pada sebagian orang predikat ini sebagai pilihan yang tidak bisa dihindarinya karena kesalahan dalam mind-set (kerangka berpikir). Menurut Khair (2013) manusia adalah theomorfic being yang memiliki intelegensi, kehendak, dan kemampuan mengungkapkan. Kapabilitas tersebut membuat manusia dapat membedakan kebenaran dari kesalahan, atau kenyataan dari illusi, dan dapat memilih secara bebas pilihan- pilihan tersebut, serta dapat mengungkapkan hubungan antara yang bersifat wahyu dan manusia. Kelemahan berfikir inilah yang menyebabkan seseorang berada dalam lingkaran kehidupan premanisme.

Menurut Simanjuntak (2007), istilah preman pertama kali dikenal di kota Medan, Sumatra Utara, sejak jaman Belanda. Kata preman berasal dari bahasa Belanda vrije man dan istilah ini melekat pada kaum lelaki yang menolak bekerja di perkebunan Belanda. Makna kata tersebut adalah lelaki bebas yang tidak dapat diatur penjajah (Mandang, 2015). Pada masa itu, Belanda sangat membutuhkan tenaga kerja laki-laki untuk perkebunan, namun terdapat sebagian masyarakat yang menolak dipekerjakan, sehingga ia memilih bebas. Hal ini tentunya bukan tanpa resiko atas ancaman Belanda atas penolakan dipekerjakan, bagi yang mampu berani menolak inilah preman yang terkadang ditakuti oleh Belanda, sehingga tak mengherankan preman ini dimanfaatkan oleh masyarakat untuk melindunginya diri dari perlakuan Belanda.

Sekarang istilah preman telah mengalami perubahan, baik peran maupun tujuannya dalam masyarakat. Pada umumnya preman merupakan orang yang berjiwa bebas untuk berperilaku sehingga membuat resah, merasa tidak aman, merugikan masyarakat dalam mempertahankan hidupnya. Untuk mendapatkan penghasilan atau mencari nafkah, ia tak segan-segan preman melakukan perbuatan yang melanggar norma, adat istiadat, agama yang berlaku di masyarakat, padahal Allah SWT menciptakan manusia dalam keadaan sebaik-baiknya. Sebagaimana tersurat dalam Al-Qur'an: "laqad khalaqnal-insāna fi aḥsani taqwīm," (Sesungguhnya Kami telah menciptakan manusia dalam bentuk yang sebaik-baiknya" (QS. At-Tiin:4). Pada dasarnya, manusia diciptakan dengan memegang peran ganda, yakni sebagai hamba yang berkewajiban untuk beribadah kepada Allah SWT, Sang Maha Pencipta, sekaligus manusia sebagai khalifah yang berdimensi sosial sehingga mampu merawat dan memakmurkan bumi (Wahid, 2016).

Dalam Al-Qur'an secara tegas dinyatakan:" huwallażi ja'alakum khalā îfa fil-ard, fa mang kafara fa 'alaihi kufruh, wa lā yazīdul-kāfirina kufruhum 'inda rabbihim illā maqtā, wa lā yazīdulkāfirīna kufruhum illā khasāā̄" (Dia-lah yang menjadikan kamu khalifah-khalifah di muka bumi. 
Barangsiapa yang kafir, Maka (akibat) kekafirannya menimpa dirinya sendiri. dan kekafiran orangorang yang kafir itu tidak lain hanyalah akan menambah kemurkaan pada sisi Tuhannya dan kekafiran orang-orang yang kafir itu tidak lain hanyalah akan menambah kerugian mereka belaka)" (QS Al-Fatir:39). Ayat ini, selain memberi petunjuk juga menegaskan tentang kemurkaan Allah SWT terhadap manusia yang melalaikannya, yaitu menambah kerugian kepada pelakunya juga orang lain serta kerusakan pada lingkungan. "wabtagi fimāa ātākallāhud-dāral-ākhirata wa lā tansa nașībaka minad-dun-yā wa ạ̣sing kamā aḥsanallāhu ilaika wa lā tabgil-fasāda fil-arḍ, innallāha lā yuhibbul-mufsidin (Dan carilah pada apa yang telah dianugerahkan Allah kepada kamu (kebahagiaan) negeri akhirat, dan jangan kamu lupakan bahagianmu dari (kenikmatan) duniawi, dan berbuat baiklah kepada orang lain sebagaimana Allah telah berbuat baik kepada kamu, dan janganlah kamu berbuat kerusakan di (muka) bumi. Sesungguhnya Allah tidak menyukai orangorang yang berbuat kerusakan)" (QS. Al-Qashash:77).

Dua ayat tersebut di atas merupakan isyarat yang mendalam bahwa Allah telah menebar anugrah kebahagiaan di akhirat tanpa harus melepas kebahagiaan dunia dengan cara berbuat baik. Dalam realitanya masih terdapat sekelompok orang yang menganggap dirinya tidak berdaya untuk berbuat baik seperti menjadi preman dalam sistem mempertahankan hidupnya. Banyak kajian yang membahas premanisme sebagai kejahatan dan perilaku menyimpang. Seperti Runturambi (2017), mengungkapkan, kejahatan dan perilaku menyimpang dalam sejarah dan kebudayaan Indonesia mulai diuraikan melalui peran sosial para jagoan, bandit, kecu, begal, preman, dan seterusnya. Istilah jagoan telah berlangsung sejak masa pra kolonial, bahkan masa kerajaan di Nusantara hingga berlanjut ke masa Indonesia merdeka. Pendapat ini didukung juga oleh Makaampoh (2013), bahwa aktivitas premanisme di Indonesia sudah ada sejak jaman penjajahan kolonial Belanda.

Ada beberapa faktor yang menjadi pemicu munculnya perilaku premanisme yang nampaknya makin marak di Indonesia, terutama di kota-kota besar. Tadjuddin (2013), mengungkapkan ditemukan beberapa alasan mengenai semakin maraknya aksi kejahatan yang dilakukan oleh preman di Kota Makassar antara lain: tersedianya waktu luang yang tidak dapat digunakan untuk kegiatan-kegiatan lain, pola hidup yang bebas yang dibarengi dengan berkurangnya gairah kerja atau kesempatan kerja, sikap dan pandangan hidup individu dan masyarakat terhadap preman itu sendiri. Tidak sedikit sekelompok masyarakat memilih alternatif menjadi preman dalam rangka mencari nafkah, cukup bermodal keberanian bela diri (biasanya memiliki ilmu kebal), dan bersikap tega merugikan orang lain maka jadilah preman, baik secara sendiri-sendiri maupun kelompok.

Faktor lain yang menyebabkan preman melakukan kejahatan di wilayah hukum Polda Bali meliputi faktor internal yakni tingkat pendidikan dan kematangan berpikir dan faktor eksternal yang meliputi kondisi ekonomi, lapangan kerja, lingkungan dan alkohol, serta kesenjangan sosial (Pradipta \& Suardana, 2017). Kesenjangan sosial tidak hanya terjadi di wilayah hukum Polda Bali, tetapi nampaknya merata di seluruh Indonesia. Pandangan yang sama juga tentang premanisme dikemukakan oleh Sofian (2012), bahwa faktor penyebab terjadinya premanisme karena desakan untuk dapat memenuhi kebutuhan yang sulit terpenuhi karena kemiskinan, kebutuhan akan keselamatan, ketertiban, dan bebas dari rasa takut dan ancaman bisa membuat orang melakukan tindakan yang menjurus pada sikap premanisme yangmerupakan suatu budaya sendiri (sub culture) yang terlepas dari budaya dominan. 
Peneliti lain memberi kesimpulan bahwa munculnya premanisme juga akibat rendahnya pendidikan seseorang sehingga mereka menghalalkan segala cara untuk dapat bertahan hidup (Sriasih \& Trilaksana, 2014). Meskipun kesimpulan ini nampaknya sederhana, namun tak dapat dipungkiri bahwa orang yang berpendidikan tinggi dapat berperilaku preman yang dampaknya jauh lebih dahsyat dibanding preman pendidikan rendah. Jika preman berpendidikan rendah mungkin hanya berdampak pada skala yang kecil, tetapi bagi yang berpendidikan tinggi bisa berdampak skala nasional dan merusak sistem tatanan sosial. Bandingkan, seorang kakek yang mencuri kayu bakar di lahan perkebunan milik pemerintah dengan pejabat pemerintah yang mencuri uang untuk biaya pembuatan e-KTP. Sebut saja para anggota DPR yang sejak rezim Orde Baru sampai sekarang hanya berbeda dalam gaya. Sedang esensi tetap sama, mereka tidak benarbenar mewakili dan memperjuangkan kepentingan rakyat yang diwakili (Khair, 2013).

Tadjuddin (2013) menyimpulkan pendapat Ketua Presidium Indonesia Police Watch, setidaknya ada empat model preman yang ada di Indonesia, yaitu: Preman yang tidak terorganisasi. Mereka bekerja secara sendiri-sendiri, atau berkelompok, namun hanya bersifat sementara tanpa memiliki ikatan tegas dan jelas. Preman yang memiliki pimpinan dan mempunyai daerah kekuasaan. Preman terorganisasi, namun anggotanya yang menyetorkan uang kepada pimpinan. Preman berkelompok, dengan menggunakan bendera organisasi. Biasanya preman seperti ini, dibayar untuk mengerjakan pekerjaan tertentu. Berbeda dengan preman jenis ketiga, karena preman jenis ini biasanya pimpinanlah yang membayar atau menggaji anak buahnya. Preman jenis keempat ini, masuk kategori preman berdasi yang wilayah kerjanya menengah ke atas, meliputi area politik, birokrasi, dan bisnis gelap dalam skala kelas atas. Dalam operasinya, tidak sedikit di antara mereka di-backup aparat. Kerjanya rapih, dan sulit tersentuh hukum, karena hukum dapat mereka beli, dengan memperalat para aparatnya.

Peran aparat inilah yang menjadi salah satu penyebab premanisme di Indonesia semakin meningkat, baik dalam kuantitas maupun kualitas. Meskipun demikian, masih ada upaya yang dilakukan oleh pihak berwenang untuk menekan kejahatan dan keresahan yang dimbulkan oleh perilaku premanisme. Seperti upaya kepolisian dalam menyelesaikan tindakan premanisme di wilayah hukum Polda Bali meliputi tindakan represif diantaranya penyidikan terhadap jaringan preman, penangkapan, pembinaan serta tindakan preventif meliputi pelatihan, penyuluhan dan sosialisasi kepada masyarakat (Pradipta \& Suardana, 2017). Pencegahan yang paling ekstrim pun pernah dilakukan, yaitu melalui pembunuhan misterius dilakukan dengan menculik dan membunuh orang-orang yang dianggap menggangu keamanan masyarakat kemudian mayatnya digeletakkan begitu saja dipinggir jalan (Sriasih \& Trilaksana, 2014).

Sebenarnya telah banyak upaya yang dilakukan untuk mengurangi dampak premanisme, namun belum memberikan hasil yang diharapkan. Memang terdapat kendala yang dihadapi oleh pelaku premanisme untuk dapat hidup berbaur dengan masyarakat sesuai norma, adat istiadat yang berlaku. Inti persoalan premanisme sebenarnya bukan pada kondisi tatanan masyarakat yang ada, tetapi justru terletak pada individu yang bersangkutan. Mentalitas pada umumnya sangat rapuh sehingga tidak mampu menghadapi kondisi sosial-ekonomi masyarakat yang bergerak pesat. Maka dari itu, upaya yang sangat strategis dalam mencegah aksi premanisme adalah mengembalikan pelaku pada fitrah jati dirinya dengan kontribusi utama pada yang bersangkutan. Artinya faktor diri menjadi penentu keberhasilan mengubah dirinya menjadi baik dan berakhlak mulia. Sebagaimana firman Allah SWT dalam Al-Qur'an:" lahụ mu'aqqibātum mim baini yadaihi wa min khalfihī yahfazụnahụ min amrillāh, innallāha lā yugayyiru mā biqaumin hattā yugayyirụ mā 
bi 'anfusihim, wa iżā arādallāhu biqaumin sū'an fa lā maradda lah, wa mā lahum min dụnihī miw wāl" (Sesungguhnya Allah tidak akan mengubah keadaan suatu kaum sehingga mereka mengubah keadaan yang ada pada diri mereka sendiri") (QS Ar-Rad:11). Dengan demikian, perlu ada kerelaan untuk mengubah perilaku dirinya menjadi baik, biasanya dilakukan melalui pertaubatan.

Terdapat faktor pendukung internal dan eksternal dalam proses taubat, internal berasal dari diri individu yaitu evaluasi diri, motivasi diri dan kontrol diri, sedangkan faktor eksternal adalah stimulus, dukungan teman sebaya, bimbingan intens dan dukungan social (Fachitiandi, 2018). Dalam beberapa kasus, pendekatan pertaubatan dipandang efektif sebagai terapi mengembalikan pelaku premanisme kepada jalan yang benar. Ada tiga syarat untuk bertauabat, yang pertama hendaklah menghentikan seketika itu juga dari kemaksiatan yang dilakukan, kedua ialah supaya menyesali kesalahannya kerana telah melakukan kemaksiatan. dan yang terakhir adalah berniat tidak akan mengulangi lagi perbuatan maksiat itu untuk selama-lamanya (Zunaidi, 2018). Fungsi taubat dalam psikoterapi memegang peranan penting dalam proses penyembuhan dan mengembalikan kembali potensi fitrah yang dimiliki seseorang (Shohib, 2015).

Melakukan taubat bisa dilakukan secara mandiri maupun bantuan orang lain, dilakukan secara sukarela sendiri-sendiri atau melalui organisasi seperti yang dilakukan lembaga swadaya masyarakat. Kajian ini pada awalnya berfokus pada perilaku premanisme dan faktor-faktor yang mempengaruhinya. Akan tetapi selama pengamatan terhadap subyek, subyek mengalami perubahan perilaku kearah pertaubatan yang dilakukan subyek. Barigno yang dikenal memiliki jiwa premanisme, mengubah jalan hidupnya secara sukarela untuk kembali kepada kehidupan bermasyarakat secara normal. Setidaknya ada tiga pertanyaan yang menarik dari kasus pertaubatan sang preman Barigno, yaitu: (1) apakah pertaubatan yang dilakukan Barigno atas inisiatif dirinya sendiri, (2) faktor-faktor apa yang mempengaruhinya sehingga dalam hitungan waktu relatif sangat singkat, Barigno melakukan pertaubatan, dan (3) apakah perilaku pertaubatan yang dilakukan Barigno berdampak positif pada teman-temannya. Melalui kajian ini diharapkan diperoleh gambaran bagaimana proses, pola, faktor dan makna pertaubatan yang dilakukannya. Dengan demikian, kajian terhadap perilaku pertaubatan Barigno menjadi penting dalam upaya mencari model taubat yang relevan bagi pelaku premanisme atau kejahatan lainnya.

\section{METODE PENELITIAN}

Metode penelitian ini menggunakan pendekatan kualitatif studi kasus. Sampel pada penelitian ini menggunakan teknik purposive sampling, sedangkan key informan menggunakan teknik snowball sampling. Fokus utama penelitian ini adalah perilaku kesadaran beragama seorang preman bernama Barigno sesuai fitrahnya. Kajian ini lebih bersifat biografi seseorang dalam perjalanan hidupnya menuju kepada kesadaran beragama yang dianutnya. Data penelitian dikumpulkan melalui observasi, wawancara, kuesioner sebagai pedoman, dan dokumentasi. Peneliti menyadari, bahwa dalam wawancara untuk menggali informasi, sering terjadi percakapan yang tidak fokus. Oleh karena itu, peneliti menggunakan kuesioner sebagai panduan wawancara yang implementasinya seperti percakapan pada umumnya.

Fokus lain dari penelitian ini adalah pelaku atau aktor (subyek) serta tempat kejadian tersebut. Hal ini sesuai dengan pandangan kualitatif, bahwa suatu perilaku kesadaran beragama pada diri Barigno tidak bersifat tunggal, tetapi melibatkan aspek tempat, pelaku, dan aktivitas secara holistic yang memerlukan interpretatif. Maka dari itu, kajian ini dipadukan dengan library 
research approach, yaitu jenis studi yang dilakukan melalui penelusuran pustaka untuk keperluan melengkapi interpretive perspective. Kedua pendekatan ini dipandang memadai untuk mengungkap perilaku kesadaran beragama sang preman melalui pertaubatan sehingga diperoleh pemahaman dan pengamalan yang benar pada umat muslim. Alasan memadukan dengan studi kepustakaan karena terdapat informasi yang diperlukan dalam menyelesaikan penelitian yang bersumber dari kepustakaan. Sumber informasi yang digunakan dalam studi pustaka antara lain, Al-Qur'an, hadishadis shahih, buku, jurnal ilmiah, dan sumber lain yang relevan. Studi pustaka ini masih relevan digunakan untuk mencapai tujuan research.

Studi lapangan diperlukan untuk memperoleh informasi data primer dari subyek yang mendukung tujuan penelitian. Kegiatan pengumpulan data terdiri atas kegiatan pengamatan, wawancara dengan panduan kuesioner, dan studi dokumentasi. Pengamatan dilakukan secara terlibat di lingkungan subyek penelitian di Kota Samarinda dan Ciamis mulai April 2008 sampai dengan Maret 2019. Pengambilan unit sampel partisipan menggunakan teknik purposive sampling. Pertimbangan peneliti menggunakan teknik purposive sampling, karena fokus penelitian pada perilaku satu orang partisipan, sedangkan penentuan key informan menggunakan teknik snowball sampling, dan untuk alasan etis, identitas seluruh partisipan disamarkan. Instrumen sebagai pengumpul data ialah peneliti sendiri.

Selama pengamatan terhadap subyek, telah terjadi perubahan sikap perilaku pada subyek dalam kesadaran beragama. Maka dari itu, tujuan penelitian diubah yang semula ingin mengungkap proses dan faktor-faktor yang berpengaruh terhadap perilaku premanisme diarahkan untuk menganalisis dan mengevaluasi perkembangan kesadaran beragama pada preman, sehingga diperoleh gambaran tentang proses, pola dan faktor-faktor yang mempengaruhinya. Pendekatan triangulasi data terdiri metode, sumber, dan diskusi untuk pengujian terhadap validitas dan reliabilitas data.

\section{HASIL DAN PEMBAHASAN}

Pada dasarnya kesadaran beragama seseorang telah ada dalam hatinya, namun terkadang kesadaran itu hilang sirna karena tidak dipelihara. Al Qur'an Surat Asy Syam ayat 8-10 menegaskan "fa al-hamahā fujụrahā wa taqwāhā, qad aflaḥa man zakkāhā, wa qad khāba man dassāhā (maka Dia mengilhamkan kepadanya (jalan) kejahatan dan ketaqwaannya, sungguh beruntung orang yang mensucikannya (jiwa itu), dan sungguh rugi orang yang mengotorinya) (QS Asy Syam:8-10). Firman ini secara jelas bahwa Allah SWT menyuruh hambaNya untuk selalu memelihara jiwa, dan jangan mengotorinya.

Perilaku kesadaran beragama pada diri Barigno awalnya bersifat ganda. Dalam album foto keluarga, terlihat ia memakai pakaian yang biasa digunakan untuk sembahyang dan foto sedang membaca Al Qur'an. Barigno di lingkungan tempat tinggalnya dikenal memiliki perangai yang sangat ramah dan bersahaja, tidak nampak tanda-tanda bahwa ia seorang preman yang disegani oleh teman-teman kelompoknya. Menurut tetangganya Bapak Kisran, keberadaan Barigno di rumahnya tidak menentu, terkadang dalam sebulan hanya dua hari, selebihnya tidak diketahui. Bapak Kisran mengatakan:"Duka teu terang perkawis padamelan mah, mung nguping wartos anjeuna sok ka Jakarta, Bandung atanapi ka Surabaya" (Tidak tahu tentang pekerjaannya, hanya pernah dengar ia pergi ke Jakarta, Bandung atau Surabaya) (Kisran, Komunikasi personal, 9 April 2008). Rumahnya tertata rapi yang dihuni oleh seorang istrinya, bernama Aida. Selain istrinya ada seorang anak laki-laki anak Barigno, bernama Nurdjaman serta ibu Barigno, Ibu Cicih. Perabotan 
rumah tangga tergolong lengkap tetapi tidak terkesan mewah, sederhana saja. Tingkat pendidikan Barigno hanya sampai lulus Sekolah Dasar di desanya, ia tidak bisa melanjutkan pendidikan ke tingkat SMP karena alasan biaya.

Menurut cerita ibunya Barigno :"Pun anak tahun 1980 tos ngumbara ka Bandung di damel dagang di terminal Kebon Kalapa, Cicaheum, ah kadang teu tangtos tempat dagangna" (Anak saya tahun 1980 sudah merantau ke Bandung, bekerja jualan di terminal Kebon Kelapa, Cicaheum ah terkadang tak tentu tempat jualannya) (Cicih, Komunikasi personal, 9 April 2008). Meski begitu, Aida istri Barigno dan Ibunya tidak mengetahui persis pekerjaan Barigno karena tak pernah diajak ke Bandung. Di lingkungan tempat tinggal Barigno sudah menjadi hal yang biasa, seorang laki-laki dewasa pergi merantau ke kota-kota besar untuk keperluan mencari nafkah. Dilihat dari status ekonomi, Barigno tergolong mapan, mempunyai rumah, kebun, sawah dan kolam. Istrinya membuka warung sembako untuk menambah penghasilan dan pengisi waktu luang selepas mengerjakan kegiatan dari kebun atau sawah. Bagi Barigno meninggalkan keluarga merupakan hal biasa, apalagi sekarang alat komunikasi demikian canggih, sehingga kapan saja atau dimana saja dapat dilakukan.

Sesuai dengan penuturan ibunya, Barigno mengatakan:" Abdi ngumbara ka Bandung taun 80, sesudah menikah indit ti bumi ema. Tahun 86 nembe gaduh pun anak, 'si jago tea'. Awalna mah dagang roko asongan eh geuning lami-lami janten kieu. Tapi kadang-kadang sok sina jaga pasar margi teu aman, tapi 86 awal, pulang kampung sieun aya operasi petrus" (Saya merantau ke Bandung tahun ' 80 , setelah menikah pergi dari rumah ibu. Tahun 86 punya anak laki-laki. Awalnya pedagang rokok asongan eh tapi lama-lama berubah jadi begini. Tapi terkadang disuruh menjaga pasar karena tidak aman, tapi 86 awal pulang kampung takut ada operasi petrus) (Barigno, Komunikasi personal, 9 April 2008).

Pada tahun 1980-an semasa pemerintahan Presiden Soeharto telah terjadi operasi besarbesaran dalam memberantas kejahatan yang dilakukan oleh premanisme atau lainnya. Selama di kampung, Barigno bertani di kebun atau di sawah pada siang hari, sedangkan pada malam harinya memperdalam olah kanuragan untuk bela diri. Tahun 1992 kembali ke Bandung, namun temanteman tinggal sedikit. Barigno mengatakan:"Rerencangan tos pada teu aya, kantun sakedik, malah ada teman mati tertembak di Soreang Bandung, ih mani ngabirigidig leuleus ngupingna. Tahun 92 dugi 95 jadi tukang nagihan hutang dunungan" (Teman-temannya sudah tidak ada, tinggal sedikit, malah ada teman mati tertembak di Soreng Bandung, ah gemetar lemes mendengarnya. Tahun 92 sampai 95 menjadi tukang tagih untuk majikan) (Barigno, Komunikasi personal, 9 April 2008). Memang pada operasi pemberantasan premanisme di daerah Soreang Bandung telah terjadi seseorang yang diduga preman terbunuh oleh peluru petugas kepolisian. Ini yang menjadi alasan Barigno berpindah-pindah tempat. Di Bandung, Barigno nampaknya sudah tidak memiliki banyak teman, sehingga muncul rasa takut. Wujud pertemanan dalam Al-Qur'an ditemukan dua bentuk, yaitu teman yang mengajak dalam kebaikan, dan yang mengajak pada keburukan. Urgensi pertemanan dalam Al-Qur'an, dilihat dari tujuan pertemanan yaitu: terjalinnya hubungan interaksi sosial antar sesama, terjalinnya ikatan ukhuwwah, dan terjaganya silaturahmi (Jufri, 2017). Barigno selama ini tidak memiliki teman yang membawa kepada kebaikan, malah melakukan tindakan yang buruk.

Pada awal tahun 1996, Barigno merantau ke Samarinda kemudian ke Berau, Tanah Grogot, Sangngata, Tenggarong, dan berakhir kembali di Samarinda 2009. Ia tinggal bantaran Sungai Mahakam, sekalian mengawasi lalu lalang batu-bara di Sungai Mahakam milik majikannya, Tubagus 
Maman. Bagi Barigno meraih duniawi bukan hal yang sulit, sejak marantau di Bandung dan kotakota besar lainnya termasuk Samarinda, uang selalu siap menyertai. Maka tak mengherankan jika Barigno selalu hidup di dunia gemerlap, wanita, judi, minuman, mabuk, dan terkadang perkelahian. Meski perilakunya begitu, Barigno sangat setia pada majikannya, dia sangat hormat betul sama majikannya. Barigno paham akan resiko jika bermasalah dengan majikannya akan kehilangan penghasilan sebagai sumber nafkah.

Pada pertengahan tahun 2011, Barigno sering gelisah dan susah tidur. "Sekarang saya hese sare, inget kana lalakon hirup kapungkur. Emut ka tukang sayur dicarekan pedah teu mayar kaamanan, digaplok ku abdi" (Sekarang saya susah tidur, ingat pada perjalanan hidup yang lalu. Teringat sama tukang sayur dimarahin dan ditempeleng karena tidak bayar keamanan) (Barigno, Komunikasi personal, 6 Agustus 2011). Orang yang menjadi korban kemarahan Barigno bukan tukang sayur seorang saja tapi masih banyak tukang jualan lainnya. Entah berapa wanita diperdaya yang berakhir dengan uang damai. Uang bagi Barigno adalah dewa penyelamat atas perilaku yang menyimpang. Dengan uang, Barigno bisa membeli apa yang diinginkan, uang bisa untuk membeli segalanya, termasuk harga diri pejabat.

Kegelisahan yang dialami pertengahan 2011 terus berlanjut 2013, dan sulit dihentikan. Pergi ke Pub Karaoke, main bilyar, minum-minum, dan main kartu tak mampu menghentikan kegelisahan itu. Menurut Barigno, dibenaknya selalu terbayang kakek dan neneknya mengajari dia shalat dan ngaji, merekalah yang mengajari shalat dan membaca Al-Qur'an. Barigno mengungkapkan isi hatinya:"Ti nini jeung aki belajar ngaji jeung solat, Bapak kadang-kadang, sibuk ngiderkeun dagangan. Jadi asa dosa, hampura nini, hampura aki. Ayeuna poho deui" (Dari nenek dan kakek belajar membaca Al-Qur'an dan shalat, Bapak kadang-kadang, sibuk masarkan barang. Jadi merasa berdosa, maafkan nenek, maafkan kakek) (Barigno, Komunikasi personal, 12 Juni 2013). Berdasarkan penuturan Barigno, ia belajar shalat dan mengaji (membaca Al-Qur'an) diperoleh seusia kanak-kanak. Para akhli berpendapat bahwa pendidikan masa kecil (usia dini) memiliki pengaruh terhadap pertumbuhan perilaku pada masa yang akan datang. Pendidikan pada usia dini memegang peranan yang sangat penting, karena dilakukan pada usia keemasan (golden period) anak, sehingga diharapkan memberikan dasar yang kuat dan positif bagi perkembangan anak tahap selanjutnya (Puspita, 2013). Pengalaman belajar Agama Islam pada diri Barigno pada masa kecil membawa dampak yang positif terhadap perkembangan perilaku kesadaran beragama saat dewasa.

Satu bulan menjelang hari ulang tahunnya ke 59, dia meminta peneliti untuk menemani ke sebuah pondok pesantren di kawasan Balikpapan. Di pondok pesantren itu, peneliti dan Barigno diterima seorang pengasuh pondok pesantren yang mengajaknya shalat Dzuhur berjamaah di masjid. Shalat Dzuhur di pesatren ini, bagi Barigno merupakan shalat yang pertama setelah 40 tahun ditinggalkan. Meskipun begitu, Barigno melakukan shalat seperti pada umumnya. Masih di ruangan masjid, melaksanakan dzikir bersama kemudian kembali ke ruang tamu (Pengamatan, tanggal 15 Juli 2013).

Setelah Barigno berkisah tentang perjalanan hidupnya dari awal sampai di Kalimantan, ia mendapat pecerahaan dari pengasuh pondok pesantren Bapak K.H. Amran. Bapak K.H. Amran mengatakan:"Allah maha tahu, tak perlu risau atau gelisah". Sambil memberikan pencerahan, K.H. Amran melafalkan firman Allah Surat An-Nur ayat 31:" wa qul lil-mu'mināti yagḍuḍna min abșārihinna wa yaḥfaẓna furụjahunna wa lā yubdīna zīnatahunna illā mā zahara min-hā walyaḍribna bikhumurihinna 'alā juyụbihinna wa lā yubdīna zīnatahunna illā libu'ụlatihinna au 
ābā'ihinna au ābā'ì bu'ulatihinna au abnā'ihinna au abnā ì bu'ụlatihinna au ikhwānihinna au banī ikhwānihinna au banī akhawātihinna au nisā îhinna au mā malakat aimānuhunna awittābi'îna gairi ulil-irbati minar-rijāli awiț-țiflillażīna lam yaz-harụ 'alā 'aurātin-nisā’i wa lā yaḍribna bi'arjulihinna liyu'lama mā yukhfina min zīnatihinn, wa tụbū ilallāhi jamī'an ayyuhal-mu'minụna la'allakum tuflihụn. Pada bagian akhir ayat tersebut diulangi sampai tiga kali, "(Dan bertaubatlah kepada Allah wahai semua orang yang beriman, supaya kalian beruntung") (QS. An-Nuur:31). Ketika Barigno pamitan, K.H. Amran berpesan:"Jangan gelisah Nak, semua akan baik-baik saja. Lupakan dan tinggalkan masa lalu, jangan ulangi perbuatan buruk, jangan lupa shalat fardhu dan tambah sunah, serahkan semuanya pada Allah dan biarlah Allah yang mengatur segalanya" (Pengamatan, tanggal 15 Juli 2013). Nampaknya Barigno benar-benar serius ingin bertaubat, hampir satu tahun ia berada di pondok pesantren di kawasan Martapura Kalimantan Selatan. Di pondok pesantren itulah, Barigno ditempa banyak belajar untuk kembali pada fitrahnya menjadi orang yang memiliki kesadaran beragama, ia melaksanakan perintah Allah dan menjauhi larangan-Nya. Barigno berkata sambil berseloroh:"Kang ternyata berlindung ka Allah mah gratis, beda jeung ka pulisi kudu aya pulus" (Kak ternyata berlindung pada Allah itu gratis, berbeda dengan kepada polisi harus ada pelicin) (Barigno, Komunikasi personal, tanggal 4 September 2015). Kondisi kesadaran beragama Barigno telah tumbuh baik, ia tidak lagi memiliki perlindungan lain selain kepada Allah SWT. Perjalanan kesadaran beragama Barigno telah sampai pada tingkat kesejahteraan spiritual yang akan menghantarkan dirinya pada kondisi ihsan. Secara umum proses kesejahteraan spiritual berawal dari terpenuhinya hubungan dengan diri, orang lain, alam dan transenden (Farida, 2018).

Pada awal tahun 2016, Barigno meminta peneliti untuk menemaninya pulang kampung di Ciamis, Jawa Barat. Ia telah melupakan pekerjaan dari majikannya (Pengamatan, 1 Januari 2016). Semenjak dia pulang, Barigno tidak pernah kemana-mana tapi menyibukan diri bertani di kebun dan sawah serta merawat ikan di kolamnya. Untuk mengisi waktu luang, ia sibukan diri bermain dengan cucunya, Fajar. Cucunya diperlakukan oleh Barigno seperti ia diperlakukan oleh kakek dan neneknya. Menurut Pak RT:" Tara kamana-mana, anjeuna aya bae di lembur ngasuh incuna. Sepertos akina nu kapungkur, rajin ka masigit, da kapungkur oge eta mah keluarga taat agama"(Tidak kemana-mana, dia ada di kampung menjaga cucunya. Seperti kakeknya dulu, rajin ke mesjid, dari dulu juga itu keluarga taat agama) (Haerudin, Komunikasi personal, 17 Mei 2017). Begitu juga ungkapan istrinya, Aida:"Rajin netepan, ayeunah beresih pedah sok wudu atanapi liren ngaroko panginten, nu aya mah bingah Gusti Allah maparin pituduh ka caroge" (Rajin solat, sekarang bersih mungkin karena wudlu atau merokoknya berhenti, yang ada bahagia Allah memberi petunjuk kepada suami) (Aida, Komunikasi personal, 17 Mei 2017).

Secara kasat mata, Barigno telah bertaubat melalui perjalanan yang relatif panjang dan memerlukan waktu. Pemilihan pondok pesantren sebagai titik balik kesadaran beragama dengan bertaubat merupakan langkah yang tepat, karena taubat berimplikasi pada kondisi, pengetahuan dan aksi. Lingkungan sosial merupakan salah satu faktor yang dapat mempengaruhi seseorang atau kelompok untuk dapat melakukan suatu tindakan serta perubahan-perubahan perilaku setiap individu (Sapara, Lumintang, and Paat, 2020). Pondok pesantren merupakan salah satu lembaga pendidikan yang memfokuskan diri pada pendidikan Agama Islam. Lingkungan sosial pesantren akan membantu menumbuhkembangkan perilaku seseorang kearah yang lebih baik. Manusia sebagai makhluk sosial akan saling berinteraksi dan membentuk perilaku dengan karakter tertentu. 
Menurut Bimo Walgito (2005), bahwa perilaku merupakan manifestasi kehidupan psikis. Sebagaimana yang di ketahui bahwa perilaku atau aktivitas yang ada pada individu atau organisme itu tidak timbul dengan sendirinya, tetapi sebagai akibat dengan adanya stimulus dan rangsang yang mengenai individu atau organisme itu (Sapara, Lumintang, and Paat, 2020).

Taubat merupakan kewajiban bagi setiap muslim baik laki-laki maupun perempuan yang sudah terlanjur melakukan dosa dan kesalahan, baik yang dilakukan secara sengaja atau tidak sengaja, baik yang ada hubungannya dengan Allah maupun sesama manusia. Taubat merupakan kebutuhan yang fundamental, seperti kebutuhan terhadap makan dan minum (Wahyuningsih, 2018). Selanjutnya menurut Shohib (2015) taubat pada hakekatnya mempunyai 3 (tiga) makna yang saling berurutan yaitu mengandung pengetahuan dan kesadaran ('ilm), kondisi hati ( $h a l$ ) dan tindakan ( $f^{\prime} l$ ). Meskipun begitu, taubat saja tidak cukup sempurna tetap harus mengandung kesadaran, pengetahuan, ketenangan hati dan tindakan. Menurut KH Amran, pada saat pencerahan kepada Barigno:"Setiap orang yang memiliki kesadaran beragama pasti ada rasa takut berdosa jika berbuat salah, ini perasaan biasa karena perasaan itu perlu juga untuk kontrol" (Pengamatan, tanggal 15 Juli 2013). Islam juga menjelaskan bahwa perasaan takut akan dosa memang diperlukan, ini merupakan suatu bentuk khauf (takut azab Allah) dan khashyah (gentar murka Allah)(Rusdi, 2016).

Pondok pesantren memiliki banyak fungsi, selain tempat belajar ilmu Agama Islam juga digunakan sebagai tempat perenungan untuk memperoleh ketenangan hati dan pembersihan jiwa dari sifat-sifat yang buruk. Untuk sampai pada hal tersebut, seseorang perlu aktif melakukan kegiatan yang mendukung proses penyucian jiwa. Menurut Jailani (2001), bahwa penyucian jiwa (tazkîyat al-nafs) dianggap sebagai metode Allah dalam menyucikan jiwa manusia yang diletakkan atas dasar kodrat, kemampuan naluri, fitrah dan kenyataan historis manusia. Maksudnya adalah pelaksanaan dan keberhasilan metode ini menekankan usaha manusia itu sendiri. Tanpa usaha atau mujâhadah dari orang yang akan melakukan penyucian jiwa, metode ini akan sulit terwujud dan mencapai keberhasilan. Dengan kata lain, penyucian jiwa hanya bisa direalisir dengan usaha manusia itu sendiri dalam lingkup batas kemampuan dan fitrah kemanusiaannya, serta dalam batas-batas kenyataan hidupnya (Hoddin, 2012).

Pada dasarnya selama Barigno berada di pondok pesantren merupakan proses penyucian jiwa untuk meraih ketenangan batinnya. Melalui ketenangan batin ini, Barigno tampak berbeda dalam perilaku menjadi taat pada norma agama dan tata susila. Barigno mengungkapkan perasaannya sebagai berikut:"Sayah ayeuna mah teu aya beban, hidup bisa nikmat mah pasrah ka Allah nya Kang?Babaturan oge loba nurutan sayah" (Saya sekarang tak ada beban, hidup bisa dinikmati dengan pasrah kepada Allah ya Kak? Teman-teman juga pada ikutan saya) (Barigno, Komunikasi personal, 20 Mei 2017). Dalam realitas sosial, kesadaran beragama sangat tergantung kondisi batinnya (hati), sehingga proses penyucian jiwa menjadi bagian penting untuk berperilaku baik. Penyucian jiwa berakibat terhadap ketenangan batin, tentunya berpengaruh kepada perilaku bahkan kepribadian seseorang (Hoddin, 2012). Oleh karena itu, untuk sampai pada ketenangan batin maka diwajibkan mengubah perasaan berdosa menjadi harapan ampunan dari Allah, jika tidak ada harapan, maka hanya sebuah keniscayaan saja. Proses mengarahkan perasaan berdosa menjadi hal yang baik adalah harapan. Tanpa adanya harapan akan ampunan, individu akan mengalami perasaan yang maladaptive (Rusdi, 2016).

Seseorang yang melakukan taubat, tidak serta merta tanpa tantangan, ujian demi ujian pasti akan menghampiri. Oleh karena itu harus beristiqamah dalam melakukan suruhan-Nya dan 
menjauhi daripada larangan-Nya (Zarrina, Basirah, \& Manawi, 2018), dan menggantikan keburukan yang dilakukan dengan kebaikan dan amalan yang soleh (Zarrina et al., 2018). Kehidupan manusia memiliki kewajiban berihsan dalam berhubungan dengan manusia lain di kehidupan bermasyarakat dan bernegara. Dengan demikian, maka manusia dapat menjadi khalifah yang ideal sesuai Al-Qur'an. Apalagi, ihsan merupakan tingkatan amaliyah seorang muslim yang tertinggi, setelah Iman dan Islam. Setiap muhsin (orang yang berihsan) pasti mu'min (orang yang beriman) dan setiap mu'min pasti muslim (orang islam). Namun hal ini tidak berlaku sebaliknya, di mana seorang muslim tidak tentu seorang mu`min, dan seorang mu`min tidak tentu seorang muhsin (Wahid, 2016).

Salah satu upaya untuk mencapai muhsin ialah melakukan shalat, sebagai ritual unik, yang tidak bisa ditelusuri mengapa hal itu diwajibkan dan harus dilakukan, tetapi melaksanakannya sebagai ketundukan sempurna sebagai seorang muslim. Shalat menjadi identitas melekat umat Islam yang membedakan antara umat Nabi Muhammad dengan non Islam lainnya, bahkan menjadi pembeda secara sosio-teologis antara umat Islam dengan kaum kafir (Fauzan, 2017). Barigno selalu berupaya menegakan shalat dalam kehidupan sehari-hari, karena ia yakin bahwa ibadah shalat akan menjadi pembuka bagi kegiatan ibadah lainnya. "utlu mã ụhiya ilaika minal-kitābi wa aqimișșalāh, innaș-șalāta tan-hā 'anil-faḥsyā'i wal-mungkar, walażikrullāhi akbar, wallāhu ya'lamu mā tașna'ụn (Dan dirikanlah shalat, sesungguhnya shalat itu dapat mencegah perbuatan keji dan mungkar" (QS. Al-Ankabut:45). Shalat pada dasarnya bacaan do'a untuk mencapai kondisi internalisasi tauhid secara kognitif maupun psikomotor. Shalat terdiri rangkaian bacaan demi bacaan tersebut jika disadari dan dipahami maknanya, secara bertahap menjadi momen internalisasi nilai tauhid secara kognitif dan psikomotorik dalam diri orang yang melakukannya (Fauzan, 2017).

Selama di pondok pesantren, Barigno banyak belajar tentang Islam, Iman, dan Ihsan, ketiga konsep ini merupakan satu kesatuan yang tak terpisahkan. Islam merupakan ibadah aksi atau perilaku, Iman merupakan prinsip, dan Ihsan adalah puncak hasil yang diperoleh dari seluruh kegiatan Islam berdasar pada prinsip Iman. Bagi Barigno aktivitas shalat merupakan fondasi untuk mendapatkan pertolongan Allah, sebagaimana firman Allah:" wasta'înu biṣ-ṣabri waș-ṣalāh, wa innahā lakabïratun illā 'alal-khāsyi'īn' (Dan mohonlah pertolongan (kepada Allah) melalui sabar dan shalat. Dan (shalat) itu sungguh berat, kecuali bagi orang-orang yang khusyuk") (QS. AlBaqarah: 45). Dengan demikian, ritual ibadah yang dilakukan Barigno dan umat Islam lainnya adalah untuk mendapatkan pertolongan Allah, sesuai dengan konsepsi yang dibangun kultur masyarakat yang memiliki kesadaran beragama. Meskipun kesaksian akan Tuhan yang Esa merupakan fitrah setiap orang, namun perkembangannya kesadaran akan Tuhan yang Esa itu akan terbentuk sesuai konsepsi yang dibangun di dalam kultur masyarakatnya (Fauzan, 2017).

Perjalanan religius Barigno memang panjang, namun itu suatu kenyataan yang harus dilaluinya, ia merasa yakin melalui upaya yang dilakukan dapat meraih kasih sayang Allah. Barigno selalu melaksanakan apa yang harus dilakukan. "Abdi saur kiyai dzikir nya abdi dzikir, solat nya solat. Pokona sadaya piwejang ku abdi di cumponan" (Saya kata Kiyai dzikir ya dzikir, shalat ya shalat, Pokoknya semua petunjuk oleh saya dilakukan) (Barigno, Komunikasi personal, 30 Desember 2018). Apa yang dilakukan Barigno merupakan proses pendidikan bagi dirinya untuk mencapai tujuan yang diinginkan. Menurut Khair (2013) bahwa pendidikan merupakan proses pemberdayaan dan optimalisasi potensi (fitrah) manusia di dalam menerjemahkan fungsi dan eksistensinya sebagai 'Abd Allah (spiritual) dan khalifah Allah (sosial). Tujuan yang diinginkan oleh Barigno adalah petunjuk dari Allah, yang akan Allah berikan 
kepada orang-orang yang dikehendakinya. Jalaludin (2010), menjelaskan bahwa perubahan itupun disebabkan faktor petunjuk dari Yang Maha Kuasa (Fitriani \& Setyawan, 2018). Hal ini sesuai firman Allah:" innaka lā tahdī man aḥbabta wa lākinnallāha yahdī may yasyā', wa huwa a'lamu bil-muhtadīn" (Sesungguhnya kamu tidak akan dapat memberi petunjuk kepada orang yang kamu kasihi, tetapi Allah memberi petunjuk kepada orang yang dikehendaki-Nya, dan Allah lebih mengetahui orang-orang yang mau menerima petunjuk") (QS. Al-Qashas: 56). Begitu juga pada firman yang lain-Nya:" huwallażī anzalassakīnata fi qulụbil-mu 'minīna liyazdādū ìmānam ma'a ìmānihim, wa lillāhi junụdus-samāwāti wal-ard, wa kānallāhu 'alīman ḥakīmā" (Dialah (Allah) yang menurunkan ketenangan ke dalam hati orang yang beriman, supaya keimanan mereka makin bertambah dan keimanan mereka yang telah ada") (QS. Al-Fath: 4).

\section{SIMPULAN}

Pertaubatan pada dasarnya hijrah seseorang dari perilaku yang buruk menjadi baik merupakan hal yang luar biasa, karena tantangan menuju fitrah tidak sedikit dan tidak mudah. Proses kesadaran beragama pada diri seseorang akan berlangsung sepanjang hidupnya. Hambatan terbesar pada diri seseorang untuk bertaubat adalah karena cinta dunia mengalahkan segalanya. Motivasi diri, lingkungan sosial, keluarga, dan orang-orang terdekat menjadi penentu pertaubatan yang diimplementasikan dalam perubahan perilaku. Kegelisahan yang dialami seseorang sebagai akibat perang batin atas rasa keinginan untuk membebaskan diri dari perilaku yang buruk. Usaha dan melakukan proses pembelajaran merupakan hal yang tepat, karena taubat membutuhkan pengetahuan, sikap, dan keterampilan psikomotor. Bimbingan ulama menjadi sangat penting sebagai sarana pendidikan pencerahan wawasan pengetahuan ilmu Agama Islam. Sikap bersahaja dan istiqamah sangat penting untuk memelihara taubat yang dilakukan. Pertaubatan yang dilakukan seseorang tidak cukup sampai Iman dan Islam, tetapi harus sampai pada tingkat yang tinggi, yaitu Ihsan. Pada ihsan inilah merupakan puncak aktualisasi diri seseorang sebagai hamba Allah SWT.

\section{KETERBATASAN DAN ASUMSI}

Dalam penelitian ini, peneliti menyadari terdapat keterbatasan yang tidak bisa dihindari. Hakekat taubat adalah perubahan perilaku secara bersungguh-sungguh, maka ia mendekatkan diri kepada Allah dengan taat atas segala yang diperintahkan dan menjauhi larangan-Nya. Dari aspek ritual atau peribadatan menunjukan kualitas keimanan dan ketakwaannya yang meningkat. Penelitian ini hanya mampu menjangkau perilaku fisik atau anggota badan, tidak menjangkau perilaku pikiran. Oleh karena, peneliti mengajukan asumsi bahwa perilaku seseorang berdasarkan kerangka pikirnya, apa yang dilakukan itulah yang ada dalam pikirannya.

\section{REFERENSI}

Fachitiandi, A. R. (2018). Dinamika Psikologis Pada Repentance Proses (Proses Taubat). Universitas Muhammadiyah Makassar.

Farida, G. (2018). Kesejahteraan Spiritual Pada Orang yang Mengalami Konversi Agama. Universitas Muhammadiyah Surakarta.

Fauzan, A. (2017). Membaca Fenomena Shalat Sebagai Sebuah Tanda (Telaah Kritis DialektikaNormatif dan Semiotik Tentang Shalat Wajib). Jurnal Dakwah dan Komunikasi, 2(1). https://doi.org/10.29240/jdk.v2i1.277 
Fitriani, N. R., \& Setyawan, I. (2018). Hidup Hanya Sekali, Hiduplah yang Berarti Sebuah Studi Kualitatif Pengalaman Tobat pada Mantan Preman Relawan Lembaga Sosial. Empati, 7(1), 44-53.

Hoddin, M. S. (2012). Konsep Taubat Tarekat Naqshabandiyah Muzhariyah. Teosofi, 2(1), 31-48.

Irwanto, I. (2016). Pendekatan Inter dan Lintas Disiplin dalam Penyusunan Kebijakan Pidana: Sumbangan Disiplin Ilmu Psikologi. Peradilan Indonesia, 4(1), 1-67.

Jufri, N. I. J. (2017). Pertemanan Perspektif Al- Qur'an (Suatu Tinjauan Metode Maudui). Universitas Islam Negeri Alauddin Makassar.

Khair, M. A. (2013). Restorasi Peran Pendidikan Islam Dalam Tatanan Kehidupan Sosial. Tadris, $8(2), 235-248$.

Makaampoh, M. F. (2013). Kedudukan dan Tugas Polri Untuk Memberantas Aksi Premanisme Serta Kaitannya Dengan Tindak Pidana Kekerasan Dalam KUHP. Lex et Societatis, 1(2), 71-83.

Mandang, R. s. (2015). Studi Tentang Sistem Komunikasi di Kalangan Preman Teling Atas Manado. Acta Diurna, 4(5), 1-19.

Pradipta, K. A., \& Suardana, W. I. (2017). Tinjauan Kriminologi Terhadap Kejahatan yang Dilakukan oleh Preman di Polda Bali. Universitas Udayana.

Puspita, W. A. (2013). Aspek-aspek Penting Perkembangan dan Pendidikan Anak Usia Dini. Jurnal Pendidikan Non Formal, 10, 1-20.

Runturambi, A. J. S. (2017). Makna Kejahatan dan Perilaku Menyimpang dalam Kebudayaan Indonesia. Antropologi Indonesia, 2, 125-135.

Rusdi, A. (2016). Efektivitas Shalat Taubat Dalam Meningkatkan Ketenangan Hati. Psikis, 2(2), 94116.

Sapara, M. M., Lumintang, J., \& Paat, C. J. (2020). Dampak Lingkungan Sosial Terhadap Perubahan Perilaku Remaja Perempuan di Desa Ammat Kecamatan Tampan 'Amma Kabupaten Kepulauan Talaud. Holistik, 13(3), 1-16.

Shohib, M. (2015). Taubat Sebagai Metode Dasar Psikoterapi. Seminar Psikologi \& Kemanusiaan, 978-979.

Simanjuntak, M. C. C., \& Sulistyo, H. (2007). Preman-Preman Jakarta. Jakarta: Pensil-324.

Sofian, T. (2012). Penanggulangan Premanisme di Kota Palembang Suatu Kajian Sosio Kriminologi. Universitas IBA.

Sriasih, K., \& Trilaksana, A. (2014). Premanisme di Jakarta Tahun 1974-1983. Avara, 2(2).

Supriadi, S., Yophi, S., \& Ramadhan, D. (2013). Penegakan hukum tindak pidana kekerasan premanisme di kepolisian sektor kecamatan keritang indragiri hilir.

Tadjuddin, A. S. (2013). Tinjauan Kriminologi Terhadap Kejahatan yang Dilakukan oleh Preman (Studi Kasus Polsek Tamalanrea Makassar). Universitas Hasanuddin.

Wahid, A. (2016). Konsepsi Ihsan Perspektif Al-Qur'an. IAIN Surakarta.

Wahyuningsih, I. (2018). Strategi dakwah melalui terapi taubat pada mantan preman dalam membentuk kesalehan individu (Studi Kasus Di Pondok Pesantren Istighfar Perbalan Purwosari Semarang). UIN Walisongo Semarang.

Zarrina, C., Basirah, S., \& Manawi, M. (2018). Konsep Taubat Abu Talib Al-Makki Dalam Pembangunan Psikologi Diri. Jurnal Qalbu, 5(4), 100-123.

Zunaidi, A. A. (2018). Konsep Taubat dan Implementasinya Menurut Perspektif Imam Nawawi. UIN Walisongo Semarang. 
Khazanah Theologia, Vol. 3 No. 2 (2021): 67-80

Kesadaran Beragama dalam Perspektif Ihsan: Pengalaman Pertaubatan Preman Heryanto

Halaman ini sengaja dikosongkan 